\title{
Influence of Parents Attention, Emotional Intelligence and Learning Motivation to Learning Outcomes
}

\author{
Wahyuni Ambarwati \\ SMA N 4 Sampit, Indonesia \\ E-mail: wahyuniambarwati10@gmail.com
}

\begin{abstract}
In general this research is intended to build knowledge about the extent to which the attention of parents, emotional intelligence, motivation to learn effect student learning outcomes. Therefore, the authors make the title of research is "The Effect of Parents Attention, Emotional Intelligence and Learning Motivation of Learning Outcomes Learners Educate High School 4 Sampit at 2016/2017. The purpose of this study is to determine the effect of parents' attention, emotional intelligence and motivation to learn the outcomes of learners in SMA Negeri 4 Sampit at 2016/2017. The method used in this research is multiple linear regression analysis with 76 samples. The results showed that the attention of parents, emotional intelligence, and motivation to learn partially and simultaneously have a positive and significant impact on learning outcomes of learners.
\end{abstract}

Keywords: Parents Attention, Emotional Intelligence, Learning Motivation, Learning Outcomes

\section{INTRODUCTION}

National Education Goals RI Law no. 20 Year 2003 Article 3 aims to develop the potential of students to become human the faithful and devoted to God the One, the noble, healthy, knowledgeable, skilled, creative, independent and become a citizen which is democratic and responsible. Implementation of education in Indonesia according to Law Number 20 year 2003 article 1 paragraph (2) mentioned that a National Education is education based on Pancasila and the 1945 Constitution, which is rooted in religious values Indonesia national culture and responsive to the changing demands of the times`

In order to achieve the purpose of education is necessary for the learning process, both studying in school, in the community and learning at home (family), because learning is an activity that proceeds, of course there are gradual changes. Organizing learning is one of the main tasks parents other than teachers, where learning be interpreted as an activity shown to provide learning to learners. To provide learning to learners, one the way that parents can take is by seeking his / her child can improve good learning outcomes.

The success of learners not separated from several factors, which affects, among others because of teacher factors as well as the learner factor. Teachers are learning managers or so-called learners. With his position, the teacher has a vital role in fluency ongoing learning process of learners in school. In addition to teachers, factors learners are also very influential, because learners are the subject of learning. To know the progress to where the learning outcomes, which been achieved by learners, then the evaluation should be done so it can be known high-low learning outcomes of learners. Results of field surveys related to learners' learning outcomes shows that there is a decrease; many things cause their learning results have decreased, even learners often engaging in fights with other learners. All these things closely related to learning outcomes they, therefore, need attention the more that the parent gives.

The form of attention of parents to learners seen when the school ask for the arrival of parents, which related to learners in school. Usually when the parents of the students asked to come to school though through invitations and so forth. This lack of parental attention is what can be affecting learners' interest in learning. This kind of attention is what one needs learners related to their interest in learning in school. In addition, many students who experience decline emotions that cause learners to withdraw from their environment, anxiety and problems in the form of parental concern. Learners are unable to focus or sit calm like 
daydreaming, acting without thinking, acting too tense to concentrate, unable to make up the mind so quiet, so that ultimately affects their learning outcomes.

Based on the results of interviews with teachers Guidance and Counseling SMA Negeri 4 Sampit Purwandari, S.Pd information about learners' motivation that selfassessment by learners can be seen from their initial intentions as a learner related to their purpose of going to school, whether have high or low learning motivation. It turns out that the average learner has low motivation in learning, they learn only limited to come to school and less attention from his parents. Facts above explained that the importance of a parent's attention to the child, emotional intelligence and learning motivation in the learning process and learning outcomes of learners.

From the background, the above issues can be described formulation of the problem as follows:

a. Is there any significant influence of parental attention to the learners' learning outcomes SMA Negeri 4 Sampit Lesson Year 2016/2017?

b. Is there a significant effect of emotional intelligence on learning outcomes of learners SMA Negeri 4 Sampit Lesson Year 2016/2017?

c. Is there a significant influence of learning motivation on learners' learning outcomes SMA Negeri 4 Sampit Lesson Year 2016/2017?

d. Is there a significant influence of parental attention, emotional intelligence, and motivation of learning together towards the learning outcomes of learners SMA Negeri 4 Sampit Lesson Year 2016/2017?

In accordance with background problems and problem formulation which mentioned above then the author's purpose in doing research is to influence:

a. Parents 'attention to learners' learning outcomes SMA Negeri 4 Sampit Lesson Year 2016/2017.

b. Emotional intelligence to learners' learning outcomes SMA Negeri 4 Sampit Lesson Year 2016/2017.

c. Motivation to learn to learners' learning outcomes SMA Negeri 4 Sampit Lesson Year 2016/2017.

d. Parental concern, emotional intelligence, and motivation to learn SMA Negeri 4 Sampit Lesson Year 2016/2017.

\section{LITERATURE REVIEW}

Mawarsih et.al (2013) examines the "Influence of Parents' Attention and Learning Motivation Learning against Student Achievement High School Students Jumapolo ", which aims to determine the influence of parental attention and motivation to learn to student achievement of State Senior High School Jumapolo. This research uses quantitative descriptive method with population all students of SMA Negeri Jumapolo. The sampling technique used is proportionate stratified random sampling. The results show that there is influence of attention parents and motivation to learn on the achievement of high school students Jumapolo.
Pamungkas et.al (2014) examines the "Influence of Emotional Intelligence on Mathematics Learning Outcomes in V grade students of SD Prembun Sub-district", which aims to determine the effect of emotional intelligence on mathematics learning outcomes in grade V SD students in Prembun sub-district of the academic year 2013 / 2014. This type of research is quantitative using expost facto method. Samples taken from the existing population, ie $15 \%$ of the total number of students four SD. Sampling done by random cluster sam-pling technique (area sampling). Data analysis in this research is regression analysis. The results showed that there was an effect of emotional intelligence on the learning outcomes of Mathematics in grade V SD students in Prembun District Academic Year 2013/2014.

Human resource management is one of the most important factors in a company or agency besides other factors of capital (Hariandja, 2002). Therefore, human resources must be managed well to improve the effectiveness and efficiency of the organization, as one of the functions in the company known as human resources management (Sundiman, 2017).

School-based management (MBS) comes from three words: management, based, and school. Management is the process of using resources effectively to achieve goals. Based having basic word base which means basic or principle.

The definition of human resource management above relates to development and maintenance to enhance ethical and social productivity (Wijayanti dan Sundiman, 2017). So management for learners is also in line with the tesebut. Thus, the school should pay attention to school activities related to the management of learners in order to produce learners that are efficient and have the behavior or social attitudes, spiritual learners are good, so that in accordance with the purpose of education itself. See this from the scope of student's management.

According to Sudjana in Sujarwo and Delnitawati (2013), the learning outcomes are the abilities students possess after receiving their learning experience. According to Siti (2013), the factors that influence learning outcomes classified into two parts: Internal factors, such as influenced by: a. Biological factors (physical)Physical state that needs to be considered, first the physical condition is normal or has no defect since in the womb until the birth. This normal physical condition must primarily include the state of the brain, the five senses and limbs. Second, physical health condition, healthy and fresh physical condition greatly affect the success of learning. In maintaining physical health, there are several things to note include eating and drinking regular exercise and getting enough sleep. b. Psychological factors, Psychological factors that affect the success of this study include everything that related to a person's mental. A mental condition that can support success is a stable and stable mental state (Sundiman and Idrus, 2015; Sundiman et al., 2016). These psychological factors include the following: Intelligence or the level of intelligence in a person, willingness can be said to be the main factor determining the success of one's learning, this talent is not determining the 
ability or not someone in a field, but more determine the low ability of a person in a field.

External factors, Family environmental factors, Factors of this house or family environment is the first and main environment also in determining the success of one is learning. The atmosphere of the home environment is quite calm; the attention of parents to the development of learning and education of their children will affect the success of learning. School Environmental Factors, school environment is needed to determine the success of student learning in schools include teaching methods, curriculum, teacher relationships with students, student relationships with students, lessons, time at school, discipline or discipline consistently enforced and consistent. Affects among others: teaching methods, curriculum, teacher and student relationships, school discipline, lessons and school time, standard lessons, building conditions, learning methods and home tasks. Environmental Factors Society, a student should be able to choose an environment that can support the success of learning. Society is an internal factor that also affects student learning because of its existence in society. The environments that can support the learning achievements include non-formal education institutions such as foreign language courses, test guidance, adolescent recitation and others. The concern of parents is the role of parents in carrying out their duties as responsible people and give attention through the energy, thoughts and feelings towards children ranging from guiding, attention to the growth and development of children up to education.

Aspects of parental concern according to Dakir in Siti (2009) as follows: First, Physical, Parents' concerns can manifest in the fulfillment of material needs of providing a place of learning, giving learning tools, giving a gift while achieving, maintaining the child's body health, giving money for learning purposes. Second, Psychic, Parental concerns that are psychic that is directing to choose friends hanging out, control the TV spectacle, control reading and control children activities. According to Goleman in Hamzah (2006: 71) Emotional intelligence is the ability to recognize themselves, understand themselves, and effectively apply the power and emotional sensitivity as a source of information, connections and human influence.

Goleman in Hamzah (2006) describes aspects of emotional intelligence as follows: Self Awareness Recognizing the emotions of the self is knowing what is felt and using it for decision making: realistic, confident, and confident in the abilities. 2. Managing Emotions or SelfControl, managing emotions means dealing with feelings revealed precisely. Emotions are said to be successfully managed if able to entertain themselves when overwritten sadness, can release anxiety, moodiness or irritation and rise again quickly. 3. Motivating Self (Motivating Own self), Motivating yourself is having a strong passion and moving it and guiding itself toward goals, initiative in action, and not easily despair. 4. Recognizing the Emotions of Others (Emphaty), Empathy or recognizing the emotions of others built on self-awareness. Goleman states that "Failure to record the feelings of others is a major deficiency in emotional intelligence, and the saddest defects as a human being, and every relationship is the root of caring comes from the emotional adjustment of the ability to empathize. 5 . Building Relationships with others, art in fostering relationships with other people is a social skill to support the success in association with others. Without this skill one will have difficulty in social intercourse.

Motivation to learn is a form of encouragement to learn that arises by the existence of a good thing from an individual self or from the environment. Gottried in Sudjana (2006) also suggests that high learning motivation consists of several aspects, namely: The pleasure of enjoyment to learn is to pay attention and interest to the activities and to be happy while doing schoolwork. Orientation to the mastery of the material, an ability obtained by students by mastering the materials presented in the school. The desire to know, the desire of students who motivate individuals to seek new things and look for it further. Resilience in doing the task, the student focuses entirely on completing the task and does not give up easily or despair. High involvement in the task, students are diligent in doing the task, concentrating on the task and taking the time to learn. Orientation to challenging, difficult and new tasks, thermocultured students to complete difficult or new tasks rather than easy or routine tasks.

\section{METHODOLOGY}

This research was conducted on 12 March to 01 May 2017 Lesson Year 2016/2017 in SMA Negeri 4 Sampit J1. General Sudirman KM 5.5 Sampit.The population in this study are all students of SMA Negeri 4 Sampit which can be seen in the following table:

Table I

Population Research

\begin{tabular}{clccc}
\hline No & Class & Man & Woman & Number of Students \\
\hline 1 & X MIPA 1 & 10 & 13 & 23 \\
\hline 2 & X MIPA 2 & 12 & 14 & 26 \\
\hline 3 & X IIS 1 & 15 & 11 & 26 \\
\hline 4 & X IIS 2 & 18 & 10 & 28 \\
\hline 5 & XI IPA 1 & 9 & 12 & 21 \\
\hline 6 & XI IPA 2 & 8 & 13 & 21 \\
\hline 7 & XI IPS 1 & 15 & 7 & 22 \\
\hline No & Class & Man & Woman & Number of Students \\
\hline 8 & XI IPS 2 & 15 & 10 & 25 \\
\hline 9 & XII IPA 1 & 13 & 13 & 26 \\
\hline 10 & XII IPA 2 & 12 & 13 & 29 \\
\hline 11 & XII IPS 1 & 12 & 17 & 30 \\
\hline 12 & XII IPS 2 & 12 & 18 & 302 \\
\hline & Amount & 151 & 151 &
\end{tabular}

Source: TU Staff of SMA Negeri 4 Sampit, 2017

The sampling technique used to determine the sample in this study is proportionate stratified random sampling. According to Arikunto in Son (2011) the sample is part of a population that is considered to be representative of that population, to determine the size of the sample if the subject less than 100 is better taken all so that his research population studies. However, if the larger subject can be taken between $10-15 \%$ or $20-25 \%$. 
Based on the theories presented above, the writer can determine the sample in this study for $25 \%$ of the number of learners, which can be explained in the following table:

Table II

Determination of Research Sample

\begin{tabular}{clccc}
\hline No & Class & $\begin{array}{c}\text { Number of } \\
\text { Students }\end{array}$ & Proportional & Sample \\
\hline 1 & X MIPA 1 & 23 & $=25 / 100 * 23$ & 6 \\
\hline 2 & X MIPA 2 & 26 & $=25 / 100 * 26$ & 7 \\
\hline 3 & X IIS 1 & 26 & $=25 / 100 * 26$ & 7 \\
\hline 4 & X IIS 2 & 28 & $=25 / 100 * 28$ & 7 \\
\hline 5 & XI IPA 1 & 21 & $=25 / 100 * 21$ & 5 \\
\hline 6 & XI IPA 2 & 21 & $=25 / 100 * 21$ & 5 \\
\hline 7 & XI IPS 1 & 22 & $=25 / 100 * 22$ & 6 \\
\hline 8 & X IPS 2 & 25 & $=25 / 100 * 25$ & 6 \\
\hline 9 & XII IPA 1 & 26 & $=25 / 100 * 26$ & 7 \\
\hline 10 & XII IPA 2 & 25 & $=25 / 100 * 25$ & 6 \\
\hline 11 & XII IPS 1 & 29 & $=25 / 100 * 29$ & 7 \\
\hline 12 & XII IPS 2 & 30 & $=25 / 100 * 30$ & 8 \\
\hline & Amount & $\mathbf{3 0 2}$ & & 76 \\
\hline
\end{tabular}

Based on the above table it concluded that the number of samples proportionally based on the grade with the number of samples obtained from the number of each class. The number of samples in this study as a whole is as many as 76 people learners. The way of sampling the author makes a small paper roll whose contents are sequential numbers of learners based on absences, then taken random samples with the amount corresponding to each sample of the class.

Primary data collection done by using questionnaire instrument using Likert Scale. Respondents asked to respond as well as to provide a statement that expressed in the answer to the questionnaire. To test the validity of the writer using produck moment correlation with the help of SPSS for window version 20 program, the writer compare between rhitung with rtabel. If rhitung $\geq$ rtabel then the statement is valid. Nature performs Alpha calculations, used computer programming tool that is SPSS for Windows Version 20 using Alpha model, an instrument is said to be reliable if Cronbach Alpha value is greater than 0.6.

Transform interval data aims to meet some of the requirements of the analysis. The transformation technique used in this research is a simple transformation technique using MSI (Method Of Successive Interval). MSI (Method Of Successive Interval) is a successive interval method is the process of converting ordinal data into interval data (Sarwono, 2015). To determine the result of ordinal data transformation into author interval using Microsoft Excel help.

This research uses multiple linier regression analysis technique (Multiple Regression). Data analysis in this study calculated by using SPSS for window version 20. Regression equation in this research is to know how big influence independent variable or free that is Parents attention (X1), Emotional Intelligence (X2) and Learning Motivation (X3) on learning outcomes (Y). The mathematical formulas of multiple regression used in this study are:

$$
\mathrm{Y}=\mathrm{a}+\mathrm{b} 1 \mathrm{X} 1+\mathrm{b} 2 \mathrm{X} 2+\mathrm{b} 3 \mathrm{X} 3+\mathrm{e}
$$

Information:

$\mathrm{Y} \quad=$ Learning Outcomes

a $\quad=$ Constanta

b1 = regression coefficient between parents 'attention and learners' learning outcomes

b2 = Regression coefficient between emotional intelligence and learning outcomes of learners

b3

$=$ Regression coefficient between learning motivation and learning outcomes of learners

$\mathrm{X} 1=$ Attention Parent Variable

$\mathrm{X} 2=$ Emotional Intelligence Variables

X3 = Variable Motivation Learning

$\mathrm{e}=$ error disturbances

$\mathrm{T}$ decision making (partial test): accept $\mathrm{H} 0$ if tcount $<$ ttabel ie there is no influence between each variable $X$ to variable $\mathrm{Y}$, and reject $\mathrm{H} 0$ if tcount $\geq$ ttable ie there is influence between each variable $\mathrm{X}$ to variable $\mathrm{Y}$.

Decision making test F: accept $\mathrm{H} 0$ if Fhitung <Ftabel means that independent variables do not have a mutual influence on the dependent variable. Reject H0 if Fcount $\geq$ Ftable means independent variables have a mutual influence on the dependent variable.

Furthermore to know how big influence between independent variable to dependent variable used coefficient of determination (R2). The coefficient of determination is between zero and one. A small R 2 value means the ability of the independent variables to explain the dependent variation is very limited.

Prior to data analysis, normality tests are required. Normality test performed by using kolmogorov-smirnov with the help of SPSS for window version 20 program, with decision-making criteria for data normality test is (Priyatno, 2008):

a. The significance level of kolmogorov-smirnov sig> 0,05 test shows normal distributed data

b. The significance level of kolmogorov-smirnov sig <0,05 test shows the data is not normally distributed

The multicollinearity test used to determine whether there is a classical multicollinearity assumption deviation, ie a linear relationship between the variables indevenden in the regression model (Priyatno, 2008). In this research, the technique to detect the presence or absence of multicollinearity in the regression model is to look at the value of Variance Inflation Factor (VIF). According Santoso in Priyatno (2008) in general if the VIF is greater than 5, then the variable has multicollinearity issues with other independent variables.

The heteroscedasticity test by detecting it is to see whether there is a certain pattern on the Scatterplot chart between SRESID and ZPRED, where the $\mathrm{Y}$-axis is $\mathrm{Y}$ predicted, and the $\mathrm{X}$-axis is the standardized residual ( $\mathrm{Y}$ prediction -Y). While the basic decision-making for heteroskedastisitas test is (Sarjono and Julianita, 2011):

a. If there is a certain pattern, such as the existing point form a certain pattern regular (wavy, fused and then narrowed), then indicate there has been heteroscedasticity. 
b. If there is no clear pattern, and the points spread out above and below the number 0 on the $\mathrm{Y}$ axis, there is no heteroscedasticity.

A good regression model is a regression independent of autocorrelation the autocorrelation test performed using the Durbin-Watson (D-W) test, with a 5\% confidence level. According to Sarjono and Julianita (2011) the decision of whether or not there is autocorrelation: If the DW value is between $\mathrm{dU}$ to 4 - $\mathrm{dU}$, the correlation coefficient equals zero. This means there is no autocorrelation.

\section{RESULTS AND DISCUSSION}

From the test results of the validity of the parents' attention variable, emotional intelligence and learning motivation using Pearson's Product Moment Correlation with value $(\mathrm{df}=\mathrm{n}-2) \mathrm{df}=30-2=28$ at the $5 \%$ significance level (rtabel $=0.361)$ obtained the following results :

Table III

Test Results Validity of Parents Concern (X1)

\begin{tabular}{|c|c|c|c|c|}
\hline Variable & Item & $\mathbf{r}$ & $r$ table & Information \\
\hline \multirow{7}{*}{ Parent's Attention } & $\mathrm{X}^{1.1}$ & 0,741 & \multirow{7}{*}{0,361} & Valid \\
\hline & $\mathrm{X}^{1.2}$ & 0,783 & & Valid \\
\hline & $\mathrm{X}^{1.3}$ & 0,491 & & Valid \\
\hline & $\mathrm{X}^{1.4}$ & 0,628 & & Valid \\
\hline & $\mathrm{X}^{1.5}$ & 0,513 & & Valid \\
\hline & $\mathrm{X}^{1.6}$ & 0,723 & & Valid \\
\hline & $\mathrm{X}^{1.7}$ & 0,386 & & Valid \\
\hline
\end{tabular}

Source: SPSS 20 Result for Windows, 2017

From the table above be seen that all items statement for parents' attention variable $r$-value count greater than the $r$ table it concluded that all items statements are valid.

Table IV

Validity Test Results of Variables of Emotional Intelligence (X2)

\begin{tabular}{|c|c|c|c|c|}
\hline Variable & Item & $\mathbf{r}$ & $\mathrm{r}$ table & Information \\
\hline \multirow{7}{*}{ Emotional Intelligence $\left(\mathrm{X}^{2}\right)$} & $\mathrm{X}^{2.1}$ & 0,694 & \multirow{7}{*}{0,361} & Valid \\
\hline & $\mathrm{X}^{2.2}$ & 0,677 & & Valid \\
\hline & $\mathrm{X}^{2.3}$ & 0,722 & & Valid \\
\hline & $\mathrm{X}^{2.4}$ & 0,400 & & Valid \\
\hline & $\mathrm{X}^{2.5}$ & 0,615 & & Valid \\
\hline & $\mathrm{X}^{2.6}$ & 0,570 & & Valid \\
\hline & $\mathrm{X}^{2.7}$ & 0,388 & & Valid \\
\hline
\end{tabular}

Source: SPSS 20 Result for Windows, 2017

From the table above be seen that all items statement for emotional intelligence variable $r$-value count greater than in $r$ table it be concluded that all items statements are valid.

Table V

Test Results Validity of Learning Motivation Variables (X3)

\begin{tabular}{|c|c|c|c|c|}
\hline Variable & Item & $\mathbf{r}$ & rtable & Information \\
\hline \multirow{7}{*}{$\begin{array}{l}\text { Motivation to learn } \\
\qquad\left(\mathrm{X}^{3}\right)\end{array}$} & $\mathrm{X} 3.1$ & 0,721 & \multirow{7}{*}{0,361} & Valid \\
\hline & $\mathrm{X} 3.2$ & 0,754 & & Valid \\
\hline & $\mathrm{X} 3.3$ & 0,714 & & Valid \\
\hline & $\mathrm{X} 3.4$ & 0,671 & & Valid \\
\hline & $\mathrm{X} 3.5$ & 0,746 & & Valid \\
\hline & $\mathrm{X} 3.6$ & 0,746 & & Valid \\
\hline & $\mathrm{X} 3.7$ & 0,493 & & Valid \\
\hline
\end{tabular}

Source: SPSS 20 Result for Windows, 2017
From the table above can be seen that all items statement for emotional intelligence variable $r$ value count greater than in $r$ table it can be concluded that all items statements are valid. The results of reliability test questionnaire showed that the instrument used is reliable. It is shown from the value of Cronbach's Alpha is greater than the critical number that has been set at 0.6. Reliability test results described in the following table:

Table VI

Reliability Test Results

\begin{tabular}{ccc}
\hline Variable & Cronbach's Alpha & Information \\
\hline $\mathrm{X}_{1}$ & 0,719 & Reliable \\
\hline $\mathrm{X}_{2}$ & 0,699 & Reliable \\
\hline $\mathrm{X}_{3}$ & 0,814 & Reliable
\end{tabular}

From the table above perceived that all items of parents' attention variable, emotional intelligence and learning motivation in research reliability. To know the responses of respondents based on the results of questionnaires obtained from 76 students in SMA Negeri 4 Sampit. The result of the questionnaire was calculated and the result of frequency of each answer grouped according to the variables and based on 21 answers items of parents' attention variable (X1), emotional intelligence (X2) and learning motivation (X3) and description of learning outcomes of learners can be seen In the table below:

Table VII

Description of Learning Outcomes

\begin{tabular}{|c|c|c|c|}
\hline Criteria & Value & Amount & Percentage \\
\hline Less & $\leq 73$ & 2 & $2.63 \%$ \\
\hline Enough & $74-77$ & 14 & $18.42 \%$ \\
\hline Good & $78-81$ & 43 & $56.58 \%$ \\
\hline Very good & $\leq 82$ & 17 & $22.37 \%$ \\
\hline Amount & & 76 & $100 \%$ \\
\hline
\end{tabular}

From Table VII can be seen that the value of learning outcomes of learners included in the criteria for less than 2 students or by $2.62 \%$, the criteria of enough value there are 14 students or by $18.42 \%$. The criteria of good value there are 43 Students or equal to $56.58 \%$ and the criteria of value that gets very good there are 17 students or $22.37 \%$ of the highest value of 76 students who are samples of research. Learning outcomes that be achieved by learners is because the environment is supportive, both family and school environments that provide and teach methods of learning that can improve student- learning outcomes. Both of these environments are synergistic to improve learning outcomes of learners in learning. Overall learning outcomes of learners is good. It said to be good because after the calculated average value of the students' score SMA Negeri 4 Sampit obtained from the documentation data or the value of report cards semester of $79.29 \%$. So the value is included in the category is very satisfactory. 
Table VIII

Description of Answers to the Variables of Parents Attention (X1)

\begin{tabular}{|c|c|c|c|c|c|c|}
\hline \multirow{2}{*}{ Variable } & \multirow{2}{*}{ Item } & \multicolumn{4}{|c|}{ Answer Options } & \multirow{2}{*}{ Amoun } \\
\hline & & STS (1) & TS (2) & S (3) & $\mathrm{SS}(4)$ & \\
\hline \multirow{7}{*}{$\mathrm{X} 1$} & $\mathrm{X} 1.1$ & 4 & 14 & 36 & 22 & 76 \\
\hline & $\mathrm{X} 1.2$ & 8 & 10 & 39 & 19 & 76 \\
\hline & $\mathrm{X} 1.3$ & 6 & 17 & 31 & 22 & 76 \\
\hline & $\mathrm{X} 1.4$ & 2 & 2 & 25 & 47 & 76 \\
\hline & $\mathrm{X} 1.5$ & 17 & 0 & 11 & 48 & 76 \\
\hline & X1.6 & 2 & 12 & 30 & 32 & 76 \\
\hline & $\mathrm{X} 1.7$ & 2 & 9 & 33 & 32 & 76 \\
\hline \multicolumn{2}{|c|}{ Amount } & 41 & 64 & 205 & 222 & 532 \\
\hline \multicolumn{2}{|c|}{ Percent (\%) } & $7.71 \%$ & $12.03 \%$ & $38.53 \%$ & $41.73 \%$ & $100 \%$ \\
\hline
\end{tabular}

From Table VIII above regarding respondents' answers to the statement of the parents' concern variable seen that the average respondents answered strongly disagree and do not agree. The percentage of $19.74 \%$ of the answers show that students still need attention for parents because the value of the percentage is large, On items X1.3 and X1.5 items where parents should reward prizes as they perform and pay more attention to the administration of the school. For the average respondents who answered agree and strongly agree with the percentage of $80.26 \%$, In this case the attention of parents is very important and influential in developing and supporting the ability of learners to achieve good results or learning outcomes in school learning.

Table IX

Description of Answers to the Variables of Emotional Intelligence (X2)

\begin{tabular}{|c|c|c|c|c|c|c|}
\hline \multirow{2}{*}{ Variable } & \multirow{2}{*}{ Item } & \multicolumn{4}{|c|}{ Answer Options } & \multirow[b]{2}{*}{ Amount } \\
\hline & & STS (1) & TS (2) & S (3) & $\mathrm{SS}(4)$ & \\
\hline \multirow{7}{*}{$\mathrm{X} 2$} & $\mathrm{X} 2.1$ & 2 & 5 & 39 & 30 & 76 \\
\hline & $\mathrm{X} 2.2$ & 4 & 21 & 32 & 19 & 76 \\
\hline & $\mathrm{X} 2.3$ & 2 & 1 & 36 & 37 & 76 \\
\hline & $\mathrm{X} 2.4$ & 5 & 2 & 27 & 42 & 76 \\
\hline & $\mathrm{X} 2.5$ & 10 & 0 & 14 & 52 & 76 \\
\hline & $\mathrm{X} 2.6$ & 6 & 2 & 28 & 40 & 76 \\
\hline & $\mathrm{X} 2.7$ & 4 & 17 & 35 & 20 & 76 \\
\hline \multicolumn{2}{|c|}{ Amount } & 33 & 48 & 211 & 240 & 532 \\
\hline \multicolumn{2}{|c|}{ Percent (\%) } & $6.20 \%$ & $9.02 \%$ & $39.66 \%$ & $45.11 \%$ & $100 \%$ \\
\hline
\end{tabular}

From Table IX above can be seen that the average respondent's answer to emotional intelligence variables is to agree and strongly agree, this is because emotional intelligence variables have an important role to understand, recognize the feelings of others and able to guide the mind and actions. From the table also be seen that the answers strongly disagree and disagree need attention concerning items X2.2 and item X2.5 where learners should be able to relieve the perceived anxiety and social attitudes among friends in school to increase emotional intelligence.

Table X

Description Answers Variable Motivation Learning (X3)

\begin{tabular}{|c|c|c|c|c|c|c|}
\hline \multirow{2}{*}{ Variable } & \multirow{2}{*}{ Item } & \multicolumn{4}{|c|}{ Answer Options } & \multirow{2}{*}{ Amount } \\
\hline & & STS (1) & TS (2) & S (3) & SS(4) & \\
\hline \multirow{7}{*}{$\mathrm{X} 3$} & $\mathrm{X} 3.1$ & 8 & 12 & 33 & 23 & 76 \\
\hline & $\mathrm{X} 3.2$ & 2 & 22 & 35 & 17 & 76 \\
\hline & $\mathrm{X} 3.3$ & 1 & 7 & 48 & 20 & 76 \\
\hline & $\mathrm{X} 3.4$ & 3 & 7 & 43 & 23 & 76 \\
\hline & $\mathrm{X} 3.5$ & 5 & 21 & 35 & 15 & 76 \\
\hline & $\mathrm{X} 3.6$ & 4 & 14 & 39 & 19 & 76 \\
\hline & $\mathrm{X} 3.7$ & 15 & 2 & 24 & 35 & 76 \\
\hline \multicolumn{2}{|c|}{ Amount } & 38 & 85 & 257 & 152 & 532 \\
\hline \multicolumn{2}{|c|}{ Percent (\%) } & $7.14 \%$ & $15.98 \%$ & $48.31 \%$ & $28.57 \%$ & $100 \%$ \\
\hline
\end{tabular}

Based on Table $\mathrm{X}$ above can be seen that the average respondent answered agree and strongly agree on the questions that exist in the questionnaire variable motivation learners learners. Of 76 respondents, $48.31 \%$ of respondents answered agree and $28.57 \%$ of respondents answered strongly agree. Because the motivation that exists in a learner is very important, because the motivation in learning shows the ability of a learner to encourage himself to learn this means that the average learner is motivated in learning. However, the choice of answers disagree and strongly disagree shows a large percentage of $23.12 \%$. The items are very prominent item X3.2 and X3.7 where there is a need for encouragement for learners in order to learn more enterprising, especially with regard to Tasks or homework as well as learners should be serious in learning and in accordance with the capabilities, it has.

The prerequisite test of the analysis in this study used the normality test with kolmogorov-smirnov, which aims to determine whether the samples examined are normally distributed or not.

Table XI

Normality Test Results

\begin{tabular}{cccc}
\hline & X1 & X2 & X3 \\
\hline Kolmogorov-Smirnov Z & 0,520 & 0,914 & 0,681 \\
\hline Asymp. Sig. & 0,949 & 0,374 & 0,743 \\
\hline
\end{tabular}

From Table XI can be seen that the significance value of parents' attention variable (X1), emotional intelligence (X2) and learning motivation (X3) is greater than 0.05 . Based on the normality test results it can be concluded that the data of parents' attention variable, emotional intelligence and learning motivation normal distribution. Based on the correlation matrix calculation using SPSS version 20 software can be seen the existence of multicollinearity relationship between independent variables through Variance Inflation Variable (VIF) which can be seen in Table XII below.

Table XII

Multicollinearity Test Results

\begin{tabular}{lcc}
\hline \multicolumn{1}{c}{ Variable } & Tolerance & VIF \\
\hline Concerned Parents (X1) & 0,865 & 1,130 \\
\hline Emotional Intelligence (X2) & 0,864 & 1,158 \\
\hline Learming Motivation (X3 & 0,974 & 1,027 \\
\hline
\end{tabular}

The test results showed the absence of symptoms of multicollinearity in accordance with the value of each independent variable VIF that shows a value smaller than 5, so that the model does not occur multicollinearity. Detection of heteroscedasticity in this study using scatter plot method by plotting the value of ZPRED (prediction value) with SRESID (residual value). Good models obtained if there are no particular patterns on the graph, such as collecting in the middle, narrow and then widen or otherwise widen and then narrow. Test results in Figure 1 below: 


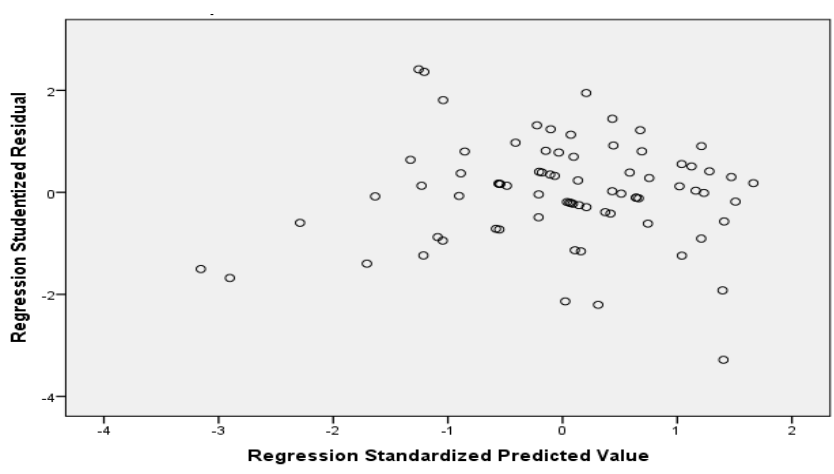

Fig. 1 Heteroscedasticity Test Results

Viewed from Figure 1 there is no particular pattern on the graph, such as gathered in the middle, narrowed then widened or otherwise widened then narrowed. Thus, the study data did not experience symptoms of heteroscedasticity.The results of the autocorrelation test seen in the following Table XIII:

Table XIII

Autocorrelation Test Results

\begin{tabular}{|l|r|r|r|r|r|}
\hline \multicolumn{7}{|c|}{ Model Summary $^{\mathrm{b}}$} \\
\hline Model & \multicolumn{1}{|c|}{$\mathrm{R}$} & R Square & $\begin{array}{c}\text { Adjusted R } \\
\text { Square }\end{array}$ & $\begin{array}{c}\text { Std. Error of the } \\
\text { Estimate }\end{array}$ & Durbin-Watson \\
\hline 1 & $.519^{\mathrm{a}}$ & .269 & .238 & 2.261 & 1.884 \\
\hline
\end{tabular}

Value $\mathrm{dL}=1.5470$

$\mathrm{DU}=1,7104$

$\mathrm{DW}=1.8844$

$\mathrm{dU}=4-1,7104=2,28964$

$\mathrm{dL}=4-1.5470=2.4530$

Table XIII results show that Durbin Watson is between dU-4 dU, that is $1.7104<1.884<2.2896$. Therefore, it be concluded that there is no autocorrelation. The statistical calculation in multiple regression analysis used in this research is using statistical software that is SPSS for windows version 20 . The result of multiple linear regression analysis seen in Table XIV below:

Table XIV

Results of Multiple Linear Regression Analysis

\begin{tabular}{|c|c|c|c|c|c|c|}
\hline \multirow{2}{*}{\multicolumn{2}{|c|}{ Model }} & \multicolumn{2}{|c|}{$\begin{array}{l}\text { Unstandardized } \\
\text { Coefficients }\end{array}$} & \multirow{2}{*}{$\begin{array}{l}\text { Standardized } \\
\text { Coefficients } \\
\text { Beta }\end{array}$} & \multirow[t]{2}{*}{$\mathrm{t}$} & \multirow[t]{2}{*}{ Sig. } \\
\hline & & B & Std. Error & & & \\
\hline & (Constant) & 66.975 & 2.444 & & 27.405 & .000 \\
\hline & CONCERNED PARENTS & .213 & .085 & .269 & 2.509 & .014 \\
\hline & EMOTIONAL INTELLIGENCE & .166 & .072 & 250 & 2.309 & .024 \\
\hline & LEARNING MOTIVATION & .156 & .064 & .251 & 2.462 & .016 \\
\hline
\end{tabular}

From Table XIV above, also be seen the equation of doubled linear regression is as follows:

$\mathrm{Y}=\mathrm{a}+\mathrm{b} 1 \mathrm{X} 1+\mathrm{b} 2 \mathrm{X} 2+\mathrm{b} 3 \mathrm{X} 3+\mathrm{e}$

$\mathrm{Y}=66.975+0,213 \mathrm{X} 1+0,166 \mathrm{X} 2+0,156 \mathrm{X} 3+\mathrm{e}$

Information:

$\mathrm{Y}=$ Learning Outcomes

$\mathrm{X} 1$ = Parent's Attention

$\mathrm{X} 2$ = Emotional Intelligence

X3 = Motivation Learning

The value of the regression coefficient of each of the above variables shows the magnitude of the influence of independent variables on the dependent variable. The greater the value of the independent variable coefficient $(\mathrm{X})$, the greater the effect on the dependent variable $(Y)$. So that can know the influence of free variable $(\mathrm{X})$ to dependent variable $(\mathrm{Y})$, that is for parent attention variable (X1) equal to 0,213 , emotional intelligence (X2) equal to 0,166 and learning motivation (X3) equal to 0,156 . From the equation above shows that the value of the regression has a positive value, which means if there is a concern given the parents of learners, the environment of learners support the development of emotional intelligence and learners are able to motivate themselves to learn to improve their learning outcomes.

To see the effect of parents 'attention variable, emotional intelligence and learning motivation to learners' learning outcomes be seen from the test described in the following test results:

Test results with SPSS obtained for the parents attention variable $(\mathrm{X} 1)$ obtained $\mathrm{t}$ value $=2.509$ with a significance level of 0.014 . The value of $t$ arithmetic compared with the value of $t$ table by using the 0.05 significance limit. $\mathrm{T}$ value table $=1.665$. Thus $\mathrm{t}$ count $>\mathrm{t}$ table is 2.509> 1.665, then Ho is rejected and Ha accepted, which means that the parental attention variable (X1) partially effect on learning outcomes (Y).

Test results with SPSS obtained for emotional intelligence variable $(\mathrm{X} 2)$ obtained $\mathrm{t}$ value $=2,309$ with a significance level of 0.024 . The value of $t$ arithmetic compared with the value of $t$ table by using the 0.05 significance limit. $\mathrm{T}$ value table $=1.665$. Thus $\mathrm{t}$ count $>\mathrm{t}$ table that is 2.309> 1.665, then Ho is rejected and Ha accepted, which means that the emotional intelligence variable (X2) partially effect on learning outcomes.

Test results with SPSS obtained for learning motivation variable $(\mathrm{X} 3)$ obtained $\mathrm{t}$ value $=2.462$ with a significance level of 0.016 . The value of $t$ arithmetic compared with the value of $t$ table by using the 0.05 significance limit. $\mathrm{T}$ value table $=1.665$. Thus $\mathrm{t}$ count $>\mathrm{t}$ table that is 2.462> 1.665, then Ho is rejected and $\mathrm{Ha}$ accepted, which means that the variable of learning motivation (X3) partially influence on learning outcomes.

With the decision making criteria: accept $\mathrm{HO}$ if Fhitung < Ftabel means that the independent variable does not have a mutual influence on the dependent variable. Reject H0 if Fcount $\geq$ Ftable means independent variables have a mutual influence on the dependent variable. The results of simultaneous test seen in Table XV as follows:

Table XV

Test Result f (Simultaneous Test)

\begin{tabular}{|rl|r|r|r|c|c|}
\hline Model & & Sum of Squares & \multicolumn{1}{c|}{ df } & Mean Square & F & Sig. \\
\hline \multirow{3}{*}{1} & Regression & 135.450 & 3 & 45.150 & 8.828 & $.000^{\mathrm{b}}$ \\
& Residual & 368.235 & 72 & 5.114 & & \\
& Total & 503.684 & 75 & & & \\
\hline
\end{tabular}

From Table XV we get the Fcount of 8,828 with significance 0.000 . While the value of Ftable at the level of trust $(\alpha=0.05)$ then obtained value Ftable $=2.73$. Thus Fcount $>$ Ftable, ie 8.828> 2.73. Therefore, H0 rejected and Ha accepted, which means that together from the attention of parents (X1), emotional intelligence (X2) and learning motivation (X3) have an effect on student learning outcomes in SMA Negeri 4 Sampit Lesson Year 2016 / 2017. The 
magnitude of the influence of parents' attention variable (X1), emotional intelligence (X2) and learning motivation (X3) on learning outcomes to student achievement variables seen in Table XVI as follows:

\section{Table XVI}

Coefficient of Determination $\left(\mathrm{R}^{2}\right)$ Model Summary ${ }^{\mathrm{b}}$

\begin{tabular}{|l|r|r|r|r|r|}
\hline Model & \multicolumn{1}{|c|}{ M } & R Squarel Summary & $\begin{array}{c}\text { Adjusted R } \\
\text { Square }\end{array}$ & $\begin{array}{c}\text { Std. Error of the } \\
\text { Estimate }\end{array}$ & Durbin-Watson \\
\hline 1 & $.519^{\mathrm{a}}$ & .269 & .238 & 2.261 & 1.884 \\
\hline
\end{tabular}

Based on the results from Table XVI above it can be seen that $\mathrm{R}$ Square has a value of 0.269 means that the parents' attention variable (X1), emotional intelligence (X2) and learning motivation (X3) give effect on learning result variable of learners equal to $26,9 \%$ and The remaining $73.1 \%$ influence other factors that have not been revealed in this study.

Variable Attention of Parents (X1) on Learning Outcomes (Y)

From the calculation of regression test shows that there is influence of parent attention to student learning outcomes SMA Negeri 4 Sampit Lesson Year 2016/2017. This means that by increasing the attention of parents to learners will be able to improve learning outcomes of learners.

Therefore there is or no attention of parents to their children it will affect the results of learning. In everyday life we often encounter various attitudes of parents to their children, if we review more deeply, among the many attitudes displayed by parents to their children there is a parent's attitude support or encourage children to excel.

The results of this study are also in line with research conducted by Mawarsih et.al (2013) which states that the influence of parents' attention on learning outcomes of learners. The role and relationship of parents with children determine the outcomes of learning. Therefore, communication and attention of parents with children is a very important role in fostering the relationship of both, it can be seen with real, for example: guiding, helping to direct, love, advise, criticize, command, pay attention and others.

Essentially, the concern of parents is a form of parental responsibility to a child whether it is about its development until it gives about what a child needs and needs as well as education for him. Because parents 'attention affects students' learning outcomes, therefore parents should raise their attention, devote to learners with a note to, really pay attention to how learners learn and learn the learning outcomes of the learners. In addition, parents also direct, and control the behavior of learners through an advice, discussion and so forth.

Variable Emotional Intelligence (X2) on Learning Outcomes (Y)

From the calculation of regression test shows that there is influence of emotional intelligence on learning outcomes of students SMA Negeri 4 Sampit Year 2016/2017 Lesson. This means that by increasing the attention of parents to learners will be able to improve learning outcomes of learners.
The results of this study also supported research conducted by Pamungkas et.al (2014) which states that there is an effect of emotional intelligence on learning outcomes of learners. Therefore, a learner should be able to assess the ability that is in him in order to be encouraged in him to learn optimally.

Emotional basic skills be had suddenly, but it takes a process in learning them and the environment that shapes emotional intelligence is of great influence. The positive will be obtained when the child is taught basic skills of emotional intelligence, emotionally will be more intelligent, understanding, easy to accept feelings and more experience in solving problems themselves, so that when teenagers will be more successful in school and in contact with colleagues, Peers. Learning outcomes only depend on the learners themselves but the support of their parents, the people around can also increase the desire to learn and improve learning outcomes, therefore the people who are environment learners should also provide support and attention to learners So that their learning results increase.

For people who are also in the environment of learners such as school environment can also affect high low emotional intelligence of learners, therefore the people who are in the environment learners should create a conducive atmosphere and give attention in order to improve emotional intelligence The learner itself.

Learning Motivation Variable (X3) on Learning Outcomes (Y)

From the calculation of regression test shows that there is influence of learning motivation to learners' achievement of SMA Negeri 4 Sampit Year of Study 2016/2017. This means that by increasing the motivation either from the learners themselves or the form of motivation from the outside of the learners will be able to improve learning outcomes. In addition, within the framework of formal education, learning motivation becomes one of the factors leading to the success of an educational program.

The results of this study also supported research conducted by Wahyudi (2015) which states that there is influence of learning motivation to learners learning outcomes. Therefore, learners need motivation for the spirit of learning both the motivation of the family environment and school environment and peers.

The results can be explained that the motivation to learn to show a positive effect on student learning outcomes. Student learning activities every day is very necessary to learn motivation in achieving good learning outcomes. With the motivation, learners will have a high learning spirit and able to create a conducive and interactive atmosphere in the learning process. Thus, motivation can also serve as stimulants in learning, because the motivation that encourages and moves learners to learn to obtain good learning outcomes.

Therefore, the cooperation between all parties, both in the school environment and the family environment to provide support and encouragement to be able to move learners to study harder, besides learners also expected not be involved in family problems that can interfere with his 
mind, thus losing Spirit and motivation to learn. Because the obligation of the learners is learning and learning, so the importance of learning motivation for learners.

Managerial Implications (Managerial Impact)

Managerial implications or the involvement of several components in improving learners' learning outcomes is the school environment and family environment, as for the following managerial implications:

a. School is able to carry out the learning, coaching and guidance in an effective, efficient manner so that each learner develops optimally in accordance with both owned in the academic and non-academic, so that the output is always in empowering in the community, by applying participative management by involving all the citizens of the school

b. Form of attention of parents whom given to the child in the form of fulfillment of physical and psychological needs. Parents should appreciate the abilities that children have so they feel valued. Growing mindset and spirit of excellence intensively to the children so that the future can be empowered in society.

\section{CONCLUSION}

\section{A. Conclusion}

In this chapter contains conclusions and suggestions based on test results and discussion of research results. The conclusion that the general formula of the research results is the basis for the next assessment in the form of suggestions in order to improve learning outcomes of learners. The conclusions in this study are as follows:

1. Partially, parents' attention variable, emotional intelligence and learning motivation have an effect on student learning outcomes of SMA Negeri 4 Sampit of Lesson 2016/2017. With the $t$ value of each variable of parental (2.509), emotional intelligence (2.309) and motivation to learn $(2,462)$ is greater than t table (1.665) with a significance level of less than 0.05 .

2. Together variables attention of parents, emotional intelligence and motivation to learn affect the results learners SMA Negeri 4 Sampit Year 2016/2017 Lesson. With $F$ value $(8,828)$ bigger than f table $(2.73)$ with significant value 0.000 .

B. Suggestion

Based on the conclusions obtained in this study, the suggested suggestions on the results of this study are as follows:

1. Parents should increase its attention, regarding the activities of learners and know the learning outcomes. When they excel in school should parents give the award of the prize to students as well as the need for concern about the administration of the school or the students' obligation, other than that people always control Patterns of child behavior through discussion, advice and so forth.

2. For people who are in the environment of the learners should create a conducive environment and also give attention and various images of experience so that learners are able to assess the capabilities that exist within himself included can eliminate the perceived anxiety and social attitudes among friends at school so Can improve emotional intelligence.

3. It needs cooperation between all parties both existing in the school environment and family environment to provide support and encouragement in order to be able to move learners to study even harder especially related to the task or homework to be completed on time and in accordance with the capabilities, it has.

4. Effect of other factors that led to the study of students, which has not been disclosed in this study include geographic factors or the location of the school SMAN 4 which is located alongside the city, almost every day there are learners who arrive late for reasons transfortasi. This needs to be a concern for parents who send their children in SMA Negeri 4 Sampit

5. Based on descriptive analysis relationship between variables known that two variables have a moderate relationship with learning outcomes are the variable attention of people and emotional intelligence, for the variable of learning motivation has a low relationship with learning outcomes. Although it has shown a good relationship but still need an increase of each variable for better learning outcomes learners.

\section{REFERENCES}

Hariandja, Marihot Tua Efendi (2002). Manajemen Sumber Daya Manusia (Pengadaan, Pengembangan, Pengkompensasian, dan Peningkatan Produktivitas Pegawai). Grasindo : Jakarta

Hamzah. (2006:71-74). Orientasi Baru Dalam Psikologi Pembelajaran. Jakarta: PT Bumi Aksara.

Mawarsih Siska Eko, Susilaningsih \& Hamidi Nurhasan (2013). Pengaruh Perhatian Orang Tua Dan Motivasi Belajar Terhadap Prestasi Belajar Siswa Sma Negeri Jumapolo. Jurnal : Universitas Sebelas Maret Yogyakarta

Pamungkas Riheni, Suhartono2, Kartika Chrysti,S3 (2014) Pengaruh Kecerdasan Emosional Terhadap Hasil Belajar Matematika Pada Siswa Kelas V Sd SeKecamatan Prembun. Jurnal: Universitas Sebelas Maret Yogyakarta

Priyatno, Dwi (2008). Mandiri Belajar SPSS (Statisticaal Product and Service Solution) Untuk Analisis data dan uji Statistik. MediaKom : Yogyakarta

Sarjono dan Julianita (2011) SPSS VS LISREL. Sebuah Aplikasi Untuk Riset. Bandung: Salemba Empat

Sarwono, Jhonatan (2015) transformasi data nominal ke interval

Siti Nurhasanah (2013) Prestasi Belajar Di Tinjau Dari Aspek Pemanfaatan Sarana Belajar (Studi Korelasi Di SMP Negeri 3 Babelan).

Siti, Nur'azizah (2009). Hubungan Antara Perhatian Orangtua Dengan Prestasi Belajar Pendidikan Agama Islam Siswa Kelas VIII SMP 2 Temon Kulon Progo. Skripsi. Universitas Islam Negeri Sunan Kalijaga Yogyakarta 
Sudjana, nana. (2006). Aspek-aspek motivasi belajar. Diakses Januari, 01, 2017 dari https://cia2pa05.wordpress.com/category/tugasstatis tika1/

Sundiman, D., \& Idrus, M. (2015). Confucianism ethic, Guanxi, and acculturation role on the knowledge transfer process of Chinese descendant in Indonesia. International Journal of Knowledge Management Studies, 6(3), 261. https//doi.org/10.1504/IJKMS.2015.072712

Sundiman, D. (2017). Human Resource Management in the Enhancement Processes of Knowledge Management. Binus Business Review, 8(3), 167-173.

Sundiman, D., \& Putra, S. S. and Mursidi, A. (2016). Knowledge Management Role on Creating Service Excellence Case Study on Building Materials Supermarket In the City of Sampit - Indonesia. In Proceedings of the The 11th International Knowledge Management in Organizations Conference on The Changing Face of Knowledge Management Impacting Society (p. 531-536). New York, NY, USA ACM.

Wijayanti, D. P., \& Sundiman, D. (2017). Pengaruh Knowledge Management Terhadap Kinerja Karyawan Studi Empiris Pada PT. SMS Kabupaten Kotawaringin Timur [The Influence of Knowledge Management toward Employee Performance An Empirical Study at PT. SMS Kotawaringin Timur District]. DeReMa (Development Research of Management) Jurnal Manajemen, 12(1), 69-85. 